\title{
Non-Coding Gene Exon Mutation
}

National Cancer Institute

\section{Source}

National Cancer Institute. Non-Coding Gene Exon Mutation. NCI Thesaurus. Code C148645.

A change in the nucleotide sequence of an exon in a non-coding gene. 